ISSN 0258-7122

Bangladesh J. Agril. Res. 38(2): 257-269, June 2013

\title{
LONG-TERM ASSESSMENT OF RICE PRODUCTION SCENARIO IN BANGLADESH: A MACRO DYNAMICS
}

\author{
M. SHAHE ALAM ${ }^{1}$ AND M. A. ISLAM ${ }^{2}$
}

\begin{abstract}
Despite high pressure of population on land and other natural resources, Bangladesh has made remarkable progress in food production over the last three and a half decades. The shrinking trend in land availability for crop production is another challenge ahead of the economy. The declining trend in cultivable land was quite sharp in the period of 1990 to 2005. Although the population has doubled, cereal food production has increased in the range of $100-125 \%$ during this period. The progress is the result of development and dissemination of modern high-yielding rice and wheat varieties supported by favourable public policies. There has been impressive technological advancement in the rice sector. Bangladesh Rice Research Institute (BRRI) made substantial contribution in the recent past and a total of 59 modern high yielding rice varieties (HYVs) suitable for different production ecologies have been released after independence in 1972. Although the progress in variety development was slower during the seventies and eightees, it was triggered up in the later decades and a quantum of achievement was made after 2000. The rate of varietal development was almost double in the last quarter of the decades compared to that made in the seventees. During the period of 1972 to 1980 , the share of modern rice in total production was only $29 \%$, but by the year 1985 , it increased to $41 \%$ and jumped to nearly $90 \%$ by 2010 implying a highly impressive contribution of the diffusion of modern rice technologies in the overall supply of cereal foods in the country.
\end{abstract}

Keywords: Long-term assessment, rice production scenario, macro dynamics.

\section{Introduction}

Bangladesh is an agro-based country with population of about 155.1 millions living in 14.84 million hectares of land. According to the estimate of World Bank, the population will have possibly increased to 230 million by the year 2030 with almost half of the people living in cities and towns (BBS, 2010). Rice is the staple dietary item for the people and per capita rice consumption is about $166 \mathrm{~kg} /$ year (BBS, 2010). Rice alone provides $76 \%$ of the calorie intake and $66 \%$ of total protein requirement (Bhuiyan et al., 2002). It employs about $43.6 \%$ of total labor forces (BBS, 2010, HIES, 2009). Rice covers about $81 \%$ of the total cropped area (BBS, 2010). Rice alone shares about $96 \%$ of the total cereal food supply. Further more, rice alone contributes about $9.5 \%$ of the total agricultural

\footnotetext{
${ }^{1 \& 2}$ Chief Scientific Officer and Scientific Officer, respectively. Agricultural Economics
} Division, Bangladesh Rice Research Institute (BRRI), Gazipur-1701, Bangladesh. 
GDP in the country. Among all crops, rice is the driving force of Bangladesh agriculture. In fact, food production in Bangladesh is dominated by a single crop (rice) and a single season (boro, which accounts for over $60 \%$ of total rice production) (MoFDM, 2012)

The topographical situation along with availability of water and sub tropical climate constitutes an excellent habitat for rice cultivation in Bangladesh. In fact, there are different rice ecosystems, namely upland (direct-seeded pre-monsoon Aus), irrigated (mainly, dry-season Boro), rainfed lowland (mainly monsoonseason transplanted Aman, medium-deep stagnant water (50-100cm), (BBS, 2009).

Although rice production in Bangladesh increased more than three folds in the last few decades, the country still could not attain sustainable self sufficiency in food. Gradual decrease of cultivable land in one hand and increased population on the other coupled with degrading natural resources and competitive world market put Bangladesh into a daunting challenge.

Ensuring food security for all is one of the major challenges in Bangladesh today. At the same breath, production and availability of food grains through proper utilization of the limited land resource base in order to meeting the demand is also a great challenge for Bangladesh. Despite the impressive achievements in food grain production during the last few decades, food supply and availability both at the households and individual level remain a major concern for the government (Shakila et al., 2008). Since rice is the main staple, food security in Bangladesh critically depends on its adequate availability and accessibility throughout the year (Mujeri et. al., 2012). However frequent occurrence of devastating floods, droughts, cyclones etc. have caused slower agricultural growth in Bangladesh resulting disruption to the overall supply of food grains.

The available statistics indicate that Bangladesh has made considerable success in agriculture in achieving near self-sufficiency in food grain (particularly rice) production. There has been quite improvement in terms of food grain availability over the years. In fact, per capita availability of rice has increased from $140 \mathrm{~kg}$ in 1972 to $180 \mathrm{~kg}$ in 2008, despite the fact that population has increased tremendously by this period implying an overall increase in food demand. Virtually, Bangladesh still imports wheat and some rice especially at times of disaster (e.g. floods, cyclone) (Hossain et al., 2009).The total food grain import in 2010-11 was about $5.31 \mathrm{mmt}$. of which $1.56 \mathrm{mmt}$ was rice and 3.75 mmt wheat (MoFDM, 2012). However, assessment of long-term cereal food supply scenario in Bangladesh with respect to the pertinent indicators could be of immense use for the researchers, planners and policy makers as well; and as such the present study was undertaken. 


\section{Objectives}

The specific objectives of the study were as follows:

i) to analyse the land use pattern for cereal food (rice) production and to document the changes in area devotion to rice production with respect to the technological advancement over time;

ii) to understand the contribution of modern rice varieties towards maintaining stability in cereal food supply; and

iii) to visualize the overall scenario in availability of cereal foods and understand the challenges ahead.

\section{Methodology}

The present study used mainly the secondary data. As such, the required data were collected from different published and unpublished reports of Bangladesh Bureau of Statistics, Directorate of Agricultural Extension, Household Income Expenditure Survey (HIES), Bangladesh Rice Research Institute and CIMMYT Bangladesh office. The collected data were then scrutinized and processed using appropriate computer software. Mainly descriptive statistics were employed in analyzing the data. Descriptive analysis was used with the aid of tabular technique to classify the generated data and to derive meaningful findings by employing mostly the measures of central dispersion (arithmetic mean, percentage and ratios, etc.).

\section{Results and Discussion}

\subsection{The scenario of land use pattern}

Land, the key natural element for crop production is considered to be the highly scarce resource in Bangladesh. The scenario of availability of the cultivable land in Bangladesh can be viewed in Table 1. The net cultivable area was about 9.38 million hectares in 1982 which has drastically declined to 8.7 million hectares by a period of only 10 years (i.e. in 1992-93). With a consistent declining trend, this area further decreased to 8.2 million hectares in 2006 implying an alarming scenario for the economy as a whole. At the same breath, the net sown area was 8.56 million hectares in 1981 which declined to 7.7 million hectares in 1993 and this remained almost stagnant upto the period of 2008-09. However, the declining ratio of the cultivable land over time has been presented in figure 1.The rate of decline in cultivable land from 1986 to 1990 was about 3.8\%. Very unfortunately the ratio of decline in cultivable land was even higher for the period of 1990 to1995 (about 4.1\%). The continuation of such decline in availability of cultivable land will of course pose serious risk in terms of domestic production and supply food crops in Bangladesh. 
Table 1. Land utilization pattern in Bangladesh: 1980-2009.

\begin{tabular}{|c|c|c|c|c|c|}
\hline Year & $\begin{array}{c}\text { Net cultivable } \\
\text { land } \\
\text { (million ha) }\end{array}$ & $\begin{array}{c}\text { Total rice area } \\
\text { (million ha) }\end{array}$ & $\begin{array}{c}\text { Net area } \\
\text { sown } \\
\text { (million ha) }\end{array}$ & $\begin{array}{c}\text { Total } \\
\text { cropped area } \\
\text { (million ha) }\end{array}$ & $\begin{array}{c}\text { Cropping } \\
\text { Intensity (\%) }\end{array}$ \\
\hline $1980-81$ & 9.38 & 10.30 & 8.56 & 13.16 & 153.74 \\
\hline 1981-82 & 9.38 & 10.45 & 8.53 & 13.20 & 153.85 \\
\hline $1982-83$ & 9.36 & 10.58 & 8.65 & 13.00 & 150.29 \\
\hline $1983-84$ & 9.46 & 10.55 & 8.68 & 13.36 & 153.92 \\
\hline 1984-85 & 9.43 & 10.22 & 8.64 & 13.15 & 152.20 \\
\hline $1985-86$ & 9.44 & 10.40 & 8.75 & 13.54 & 154.74 \\
\hline 1986-87 & 9.51 & 10.61 & 8.85 & 13.34 & 150.73 \\
\hline $1987-88$ & 9.82 & 10.32 & 8.29 & 13.82 & 166.71 \\
\hline 1988-89 & 9.84 & 10.22 & 8.15 & 13.71 & 168.22 \\
\hline $1989-90$ & 9.78 & 10.41 & 8.35 & 14.06 & 168.38 \\
\hline 1990-91 & 9.72 & 10.43 & 8.17 & 14.03 & 171.73 \\
\hline $1991-92$ & 9.09 & 10.24 & 7.98 & 13.81 & 173.06 \\
\hline 1992-93 & 8.75 & 10.18 & 7.85 & 13.70 & 174.52 \\
\hline $1993-94$ & 7.86 & 10.07 & 7.72 & 13.48 & 174.61 \\
\hline 1994-95 & 8.77 & 09.92 & 7.74 & 13.52 & 174.68 \\
\hline 1995-96 & 8.72 & 09.94 & 7.80 & 13.51 & 173.21 \\
\hline 1996-97 & 8.24 & 10.18 & 7.85 & 13.80 & 175.8 \\
\hline 1997-98 & 8.36 & 10.26 & 7.97 & 14.09 & 176.79 \\
\hline 1998-99 & 8.43 & 10.12 & 7.99 & 13.96 & 174.72 \\
\hline 1999-00 & 8.45 & 10.71 & 8.13 & 14.27 & 175.52 \\
\hline 2000-01 & 8.40 & 10.80 & 8.08 & 14.30 & 176.98 \\
\hline 2001-02 & 8.48 & 10.66 & 8.08 & 14.30 & 176.98 \\
\hline 2002-03 & 8.42 & 10.77 & 8.04 & 14.17 & 176.24 \\
\hline 2003-04 & 8.40 & 10.82 & 8.03 & 14.23 & 177.21 \\
\hline 2004-05 & 8.44 & 10.37 & 7.97 & 14.1 & 176.91 \\
\hline 2005-06 & 8.29 & 10.53 & 8.03 & 14.20 & 180.0 \\
\hline 2006-07 & 8.29 & 10.58 & 8.03 & 14.20 & 180.0 \\
\hline 2007-08 & 9.09 & 9.98 & 8.23 & 16.50 & 179.0 \\
\hline 2008-09 & 9.09 & 10.81 & 7.77 & 13.88 & 179.0 \\
\hline
\end{tabular}

Source: Bangladesh Bureau of Statistics (BBS); various volumes. 


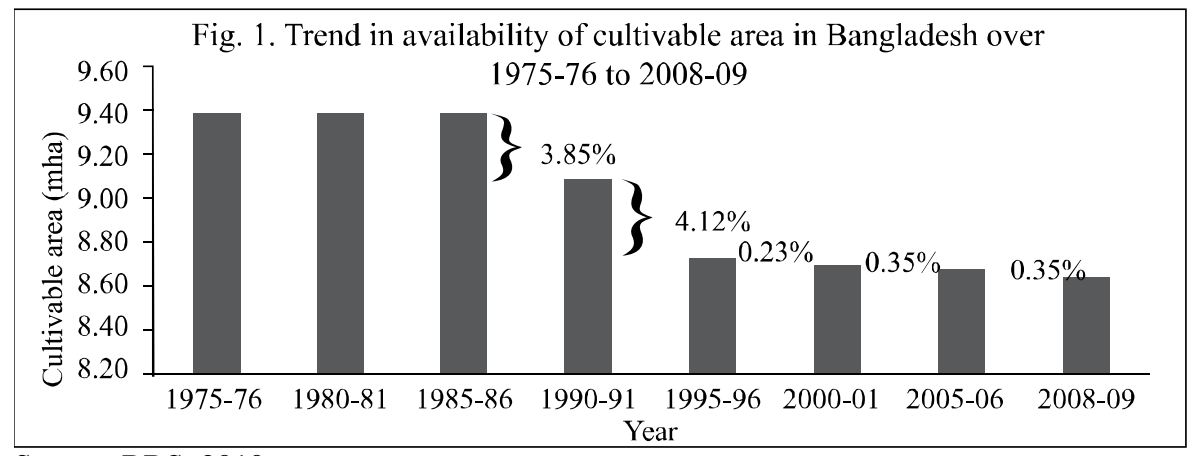

Source: BBS, 2010

The scenario of projected land availability in Bangladesh is shown in Table 2. It appears from the projection that both the net cultivable area and net sown area have had a declining trend over the years 1999-2010. The projection also indicated that, after 2010 towards 2020, in both the aforesaid land availability indicators will have sharper declining trend. The per capita availability of cultivable land will reach to 0.05 ha in 2020 which was about 0.064 ha in 2010 . In fact, there was no notable change in total cropped area (TCA) during the recent years, except that in 2007 there was an increase in TCA which was about $5.47 \%$ higher compared to that of the previous year. Actually, this was the result of increase in cropping intensity over the period under consideration. It is important to note that, area under rice production in Bangladesh has been in a consistent level over long time. Due to the availability of improved rice technologies, the harvest area of rice increased from 10.3 million ha in 1981 to 10.8 million ha in 2009.

Table 2. Projected land availability for crop production in Bangladesh, 1999-2020.

\begin{tabular}{c|c|c|c|c}
\hline Year & $\begin{array}{c}\text { Net sown area } \\
\text { (mha) }\end{array}$ & $\begin{array}{c}\text { Net cultivable area } \\
\text { (mha) }\end{array}$ & $\begin{array}{c}\text { Cropping } \\
\text { intensity (\%) }\end{array}$ & $\begin{array}{c}\text { Per capita net } \\
\text { cultivable area (ha) }\end{array}$ \\
\hline 1999 & 7.99 & 8.42 & 174.7 & 0.066 \\
2000 & 7.96 & 8.35 & 174.8 & 0.066 \\
2005 & 7.90 & 8.28 & 176.3 & 0.064 \\
2010 & 7.81 & 8.17 & 177.6 & 0.060 \\
2015 & 7.77 & 8.05 & 178.9 & 0.055 \\
2020 & 7.71 & 7.94 & 180.2 & 0.052 \\
\hline
\end{tabular}

Note: The base year is 1999 for projection

Sources: Ministry of Agriculture, GOB, (2004) and Bhuiyan et al., (2002).

\subsection{Development of modern rice varieties and their diffusion}

Bangladesh Rice Research Institute (BRRI) as the authenticated organization for carrying out research and development of high yielding modern rice technology 
has so far very successfully developed and released substantial number of rice varieties suitable for growing in different seasons. The level of varietal development by BRRI can be viewed in figure 2. In fact, there has been an increasing trend in the development of HYV rice varieties over the last three/four decades. It is important to note that, out of the total 59 HYVs evolved by BRRI so far, there are few varieties which are resistant to some abiotic stresses e.g., salinity, drought, etc. ( Saleque et al., 2005, Panaullah et al., 2000). Therefore, it is also imperative that, the diffusion of such stress tolerant varieties would take place in course of time resulting further increase in the coverage of modern varieties.

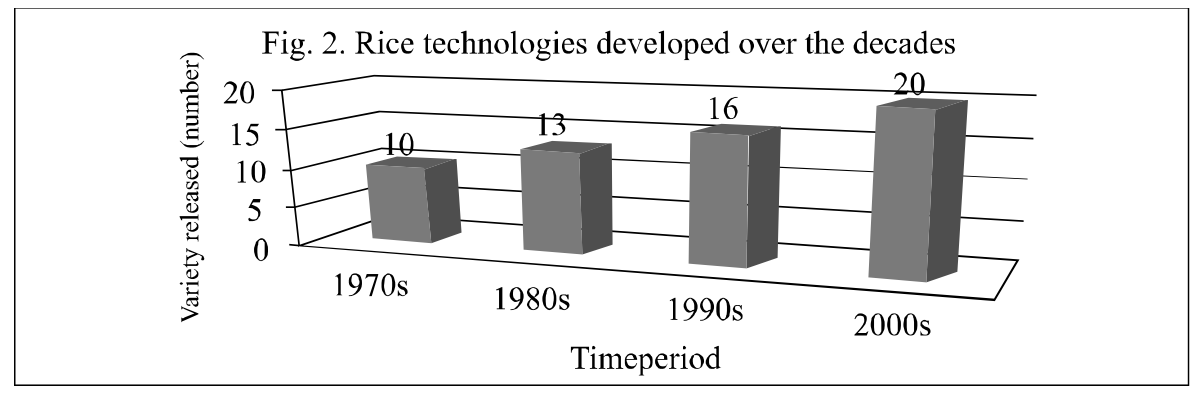

Source: BRRI, 2011.

\subsection{Changes in area devotion to modern rice production in Bangladesh}

Since rice is considered as a potential strategic commodity, after independence priority was given by each successive government to boost rice production through adoption of high yielding modern rice varieties (MVs) along with improved production technologies. Remarkable achievement was made with the introduction of MVs in the rice production scenario of Bangladesh. However, the scenario of changes in over all area devotion to modern rice varieties has been depicted in Fig. 3. The average area coverage by modern rice varieties (MVs) in the period of 1970 to 1975 was only $11 \%$, and by 1985 this coverage increased very amazingly to $34 \%$ which further increased to $57 \%$ in 2000 . According to the available statistics, the average coverage of modern rice varieties has reached 79\% during 2009. This result is in consonance with some of the earlier studies. (BRRI, 2010, Jabber and Alam, 2002). The important message is that, this progress in the diffusion of modern rice technologies is the result of: i) development and dissemination of new high-yielding rice varieties; ii) government support in the form of offering public policies like investment in irrigation and flood control, and iii) provision of subsidies on modern inputs and expansion of credit on easy terms etc.

The overall adoption of MVs was relatively slow during the seventies. However, by eighties, the coverage of modern varieties had expanded to about $34 \%$. It is remarkable that, during the later period (2000 onward), the area 
devotion to MVs was more luminous and triggered up to $66 \%$ in 2005 which further reached to almost 80\% in 2009.

The most impressive picture appeared in case of area devotion to MV Boro production. The acreage under modern Boro increased from 0.32 million ha in 1971 to 4.11 million ha in 2007 and further increased to 4.65 million ha in 2010 at the expense of very low lying and risky deepwater Aman rice and upland Aus rices (Alam et al.,2007).
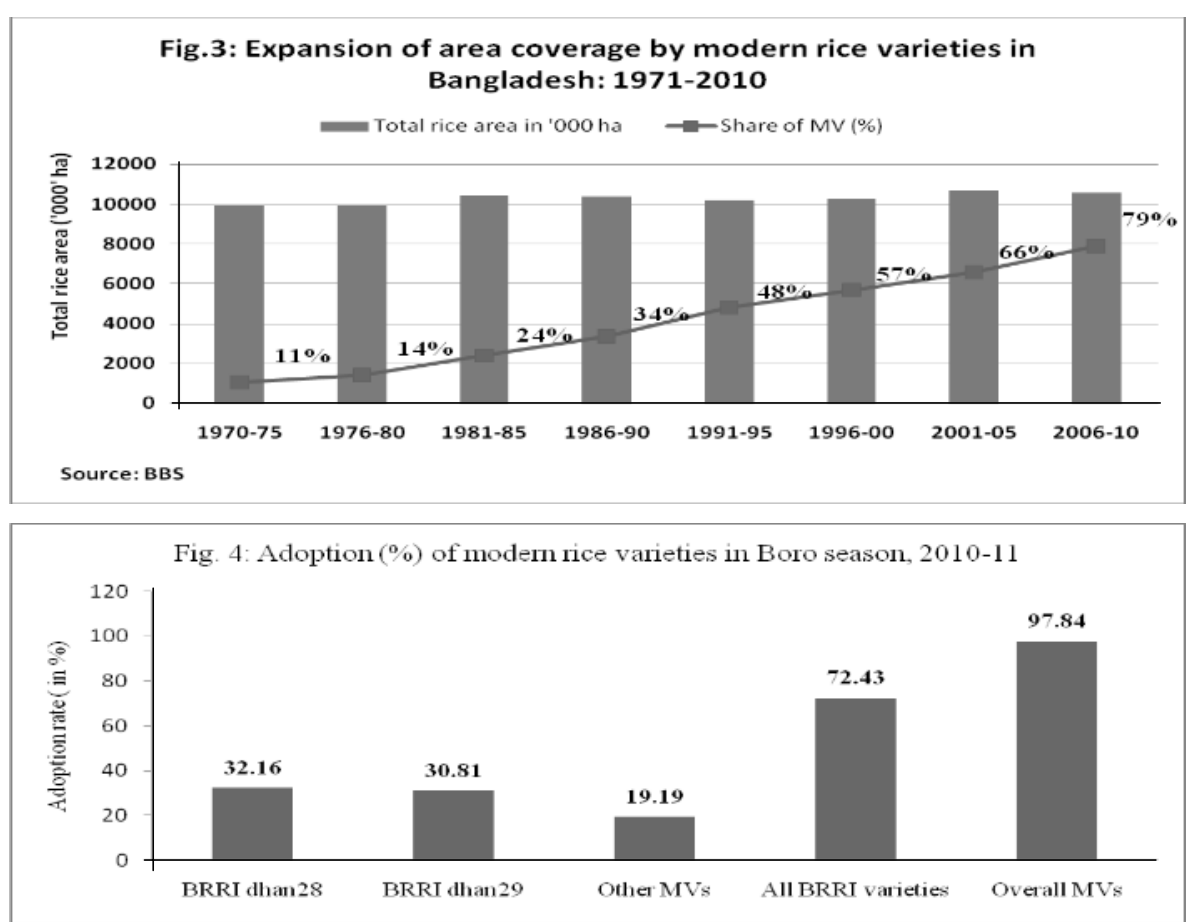

Source: BRRI Annual Review report, 2010-11. BRRI, Gazipur

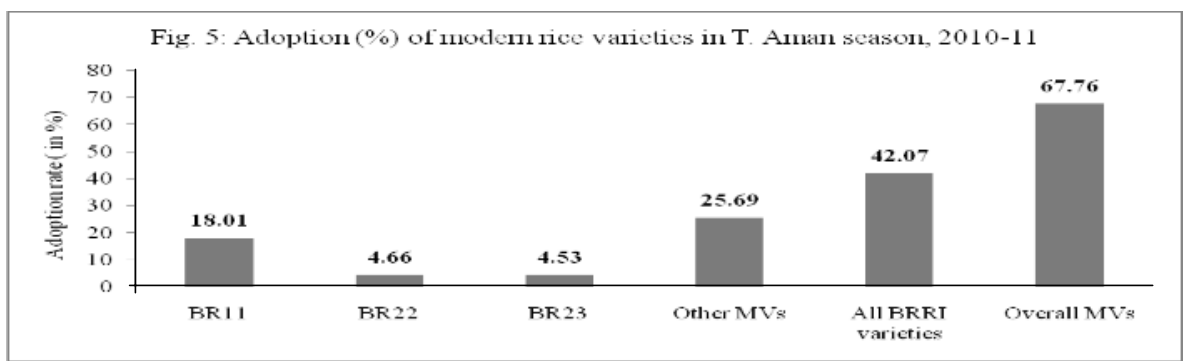

Source: BRRI Annual Review report, 2010-11. BRRI, Gazipur. 
Table 3. Annual changes in major cereal crop production over the years 2007-2011.

\begin{tabular}{c|ccccc}
\hline \multirow{2}{*}{ Cereal crops } & \multicolumn{4}{|c}{ Annual changes in production (\%) } \\
\cline { 2 - 5 } & $2007-08$ & $2008-09$ & $2009-10$ & $2010-11$ \\
\hline Rice & 5.9 & 8.2 & 2.1 & 4.9 \\
Wheat & 14.5 & 0.61 & 6.1 & 7.9 \\
Maize & 49.7 & -45.8 & 21.6 & 14.8 \\
\hline
\end{tabular}

Source:BBS, Agri.Wing, (Major and Minor crops statistics, 2011).

\subsection{Changes in production of cereal crops}

The scenario of annual changes in the production of cereal crops in Bangladesh over the period 2007-2011 can be viewed in Table 3. Production performance of the major cereal crops appears positive. In fact, rice and wheat consistently exhibited positive changes/growth rates over the years 2007-2011, while in case of maize production, the change in 2006-2007 was quite high (about 49\%), but also exhibit higher volatility in the next year. However, in the following two years the changes again showed growth of two digits. These results implied that, changes in the production of cereal crops over the recent years were quite positive and consistent.

\subsection{Contribution of modern rice to total rice production and supply}

Despite high pressure on land and other natural resources and an agrarian structure dominated by small and marginal farmers, Bangladesh has made remarkable progress in cereal food production over the last four decades. With the rapid adoption of modern rice varieties at the farm level, the total production of rice has been uplifted very amazingly. It appears in Fig. 6 that during the period 1972 to 1980 the share of modern rice in total production in the country was only $29 \%$, but by the year $1880-1985$ this share has increased to $41 \%$ and further triggered to $65 \%$ in the period of 1991-95. However, the share of modern rice to the total production has jumped to nearly $90 \%$ by $2008-09$ periods implying a highly impressive contribution of the diffusion of modern rice technologies in the over all supply of cereal food for the ever increasing population in Bangladesh.

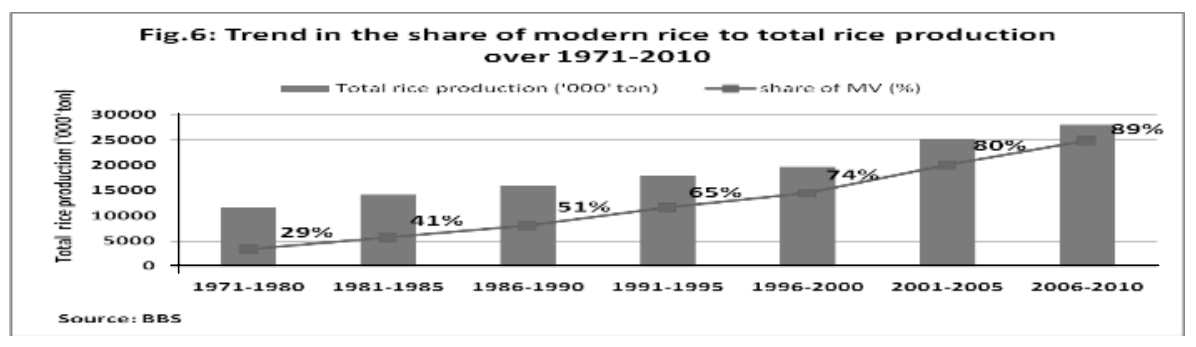




\subsection{Trend in rice yields by season and variety}

The long term trend in yield of both modern and indigenous rice varieties are furnished in Table 4. It is evident that at the very initial level ( i.e., in 1972-73), the yield of modern Boro rice was at about $3.0 \mathrm{t} / \mathrm{ha}$, but in the subsequent period of 1975 towards 1996, the yield of MV Boro had declining trend and remained almost stagnant below 3.0 tons/ha. However, with the technological advancement in the later period the yield of MV Boro increased to 3.5 t/ha during 2006 and reached at $3.8 \mathrm{t} /$ ha in 2008. Very unfortunately the yield of MV Aus gradually decreased from $2.43 \mathrm{t} / \mathrm{ha}$ in 1975 to below 2.0 t/ha during the period of 1985 towards 2000. After 2000 the yield of MV Aus had an increasing trend and reached at $2.4 \mathrm{t} / \mathrm{ha}$ in 2008. In case of modern Aman rice, although the yield was slightly below 2.0 t/ha in 1972, in the subsequent periods' yield had an increasing trend. Probably due to the availability of some new high yielding modern varieties for Aman season, the average yield reached at around $2.5 \mathrm{t} / \mathrm{ha}$ in 2009.

Table 4. Level of rice yield over the years in Bangladesh.

\begin{tabular}{|c|c|c|c|c|c|c|}
\hline \multirow{3}{*}{ Year } & \multicolumn{6}{|c|}{ Rice yield (t/ha) } \\
\hline & \multicolumn{2}{|c|}{ Aus } & \multicolumn{2}{|c|}{ Aman } & \multicolumn{2}{|c|}{ Boro } \\
\hline & MV & $\mathrm{LV}$ & MV & LV & MV & $\mathrm{LV}$ \\
\hline $1972-73$ & 2.06 & 0.74 & 1.76 & 0.89 & 3.04 & 1.31 \\
\hline $1975-76$ & 2.43 & 0.77 & 2.17 & 1.12 & 2.54 & 1.29 \\
\hline $1980-81$ & 2.21 & 0.84 & 2.14 & 1.16 & 2.67 & 1.55 \\
\hline $1984-85$ & 1.85 & 0.78 & 2.04 & 1.24 & 2.72 & 1.63 \\
\hline $1990-91$ & 1.73 & 0.94 & 2.16 & 1.29 & 2.63 & 1.44 \\
\hline 1994-95 & 1.69 & 0.87 & 2.09 & 1.17 & 2.57 & 1.33 \\
\hline $1995-96$ & 1.68 & 0.87 & 2.06 & 1.22 & 2.73 & 1.5 \\
\hline 1999-00 & 1.82 & 1.03 & 2.26 & 1.38 & 3.11 & 1.57 \\
\hline 2000-01 & 2.00 & 1.14 & 2.48 & 1.48 & 3.24 & 1.82 \\
\hline 2001-02 & 2.01 & 1.14 & 2.38 & 1.41 & 3.20 & 1.75 \\
\hline 2002-03 & 2.03 & 1.16 & 2.43 & 1.45 & 3.24 & 1.96 \\
\hline 2003-04 & 1.25 & 1.98 & 2.52 & 1.48 & 3.33 & 1.94 \\
\hline 2004-05 & 1.91 & 1.11 & 2.30 & 1.32 & 3.47 & 2.08 \\
\hline 2005-06 & 2.09 & 1.28 & 2.35 & 1.48 & 3.5 & 1.99 \\
\hline 2006-07 & 2.44 & 1.25 & 2.6 & 1.58 & 3.45 & 1.61 \\
\hline 2007-08 & 2.38 & 1.19 & 2.38 & 1.2 & 3.85 & 1.85 \\
\hline 2008-09 & 2.41 & 1.19 & 2.55 & 1.38 & 3.64 & 1.63 \\
\hline 2009-10 & 2.03 & 1.17 & 2.49 & 1.48 & 3.74 & 1.99 \\
\hline
\end{tabular}

Source: BBS, 2010; Hand Book of Agricultural Statistics, 2009. 


\subsection{The overall cereal food availability}

The scenario of cereal food availability over the years could be viewed in Table 5. The net domestic production of cereal (rice + wheat) was estimated at 17385 thousand tons in 1991-92 which has increased very consistently over the last almost two decades. In 2009-10 the domestic production reached to 29880 thousand tons. In order to keep pace with the increasing demand emanating from population growth, government kept on continuing the importation of food grains. It is worth mentioning that the volume of food grain importation has been more than double compared to the amount of 1991/92 with the amount imported in 2008-09. However, the analysis further revealed that the per capita availability of cereal food grains has amazingly increased over the years. In 1991-92, per capita availability was $165 \mathrm{~kg}$ which increased to $188 \mathrm{~kg}$ in 2001-02. Taking into consideration of the available estimate of population in the country, the per capita availability has reached to $225 \mathrm{~kg}$ in 2009-10. The development and rapid dissemination of the rice technologies during the aforesaid period have contributed much on the availability of cereal food grains in the country.

Table 5. Food grain (rice + wheat) production and availability in Bangladesh over the years.

\begin{tabular}{c|c|c|c|c}
\hline Year & $\begin{array}{c}\text { Net domestic } \\
\text { production* } \\
\text { ('000 m.ton) }\end{array}$ & $\begin{array}{c}\text { Private+public } \\
\text { import/distribution } \\
\text { ('000 m.ton) }\end{array}$ & $\begin{array}{c}\text { Total } \\
\text { availability } \\
\text { ('000 m.ton) }\end{array}$ & $\begin{array}{c}\text { per capita } \\
\text { availability } \\
\text { (kg/year) }\end{array}$ \\
\hline $1991-92$ & 17385 & 1564 & 18714 & 165.60 \\
$1995-96$ & 17150 & 2434 & 19373 & 165.50 \\
$1998-99$ & 19632 & 5212 & 24324 & 191.50 \\
$2001-02$ & 23315 & 1800 & 25006 & 188.30 \\
$2002-03$ & 24025 & 3220 & 27474 & 203.50 \\
$2003-04$ & 24698 & 2798 & 27323 & 199.44 \\
$2004-05$ & 23520 & 3371 & 26968 & 194.01 \\
$2006-07$ & 25262 & 2417 & 27770 & 194.20 \\
$2007-08$ & 26793 & 3470 & 30169 & 208.06 \\
$2008-09$ & 28944 & 3013 & 31957 & 216.42 \\
$2009-10$ & 29880 & 3454 & 33334 & 225.45 \\
\hline
\end{tabular}

* Net production - deduction as seed, feed \& wastage etc.

Source: FPMU data base on food situation, MoFDM, GOB, Dhaka, 2011.

\section{Conclusions}

Rice is the main food crop of the country and the level of cereal food supply is largely dependent on rice availability. Because of population and income growth, 
the demand for cereal foods (especially for rice) is expected to rise by over $1.5 \%$ per annum for the next few decades (Hossain et al., 2009). The main factor of production i.e., land resource base is declining very alarmingly by up to one percent a year. Per capita availability of cultivable land has been declining over time and will reach to 0.05 ha in near future from about 0.064 ha in 2010 . The continuation of such decline in availability of cultivable land will pose serious impact on the domestic production and supply of cereal foods. Nevertheless, there has been impressive achievement in technological development in the rice sector. Development and release of modern rice varieties took place at a higher rate during the later periods. Although the area coverage by modern rice varieties (MVs) during the seventees was quite low, in the later periods the dissemination got better momentum. The average coverage of modern rice varieties increased to almost 79\% during 2009-10. The progress in the diffusion of modern rice technologies is the result of; i) development and dissemination of new highyielding rice varieties; ii) government support in the form of offering public policies like investment in irrigation and flood control, and iii) provision of subsidies on modern inputs and expansion of credit on easy terms etc. With the rapid adoption of the modern rice varieties at farm level, the total production of rice has been uplifted very amazingly. Although the share of modern rice in total production was only $29 \%$ in the mid-seventees, this share triggered up to nearly $90 \%$ by 2009 implying a highly impressive contribution of the diffusion of modern rice technologies in overall supply of cereal foods.

With the technological advancement in the later decade, the yield of MV Boro increased substantially. The yield of MV Aman was slightly below $2.0 \mathrm{t} / \mathrm{ha}$ in the seventees, but had an increasing trend in the later periods probably due to the availability of new high yielding Aman varieties. The volume of food grain importation has been more than double in 2008 compared to that of some early periods. The per capita availability of cereal food grains has amazingly increased over the years. The development and rapid dissemination of the rice technologies during the aforesaid period have contributed much on the availability of cereal food grains in the country.

\section{Policy Recommendation}

Despite the impressive achievements in food grain production during the last few decades, food supply and availability both at the households and individual level remain a major concern for the government. Since rice is the main staple, food security in Bangladesh critically depends on its adequate availability and accessibility throughout the year. Frequent occurrence of devastating floods, droughts, cyclones, etc. have caused slower agricultural growth in Bangladesh resulting disruption to the overall supply of food grains. 
i) Therefore, continuation of technological advancement in the rice sector would be the key driver for sustaining availability of cereal food grains in the country.

ii) Area devotion to modern rice has already reached to a plateau implying that horizontal expansion of areas under modern rice production would be difficult. There are vast areas under abiotic stresses (e.g., salinity, flash flood, submergence, etc.), These areas need to be brought under rice production in order to boost up the level of overall productivity. Since advanced research has been able to evolve rice varieties resistant to salinity, flood, submergence (e.g., BRRIdhan47, BRRIdhan44 BRRIdhan51, etc), efforts should be made in order to disseminate the developed rice technologies to the end users in the respective production ecologies. In this connection GO-NGO partnership could be a fruitful approach in disseminating the developed technology to the doorstep of the end users at faster rate. Proper diffusion and adoption of stress tolerant rice varieties would be of great use in sustaining further growth and supply of cereal foods in the country.

iii) In order to ensure sustained productivity, provision of incentives to the producers through minimum support prices which provides adequate margin over the unit cost of production should be ensured.

\section{References}

Alam, M. S., M. A. S. Azad and M. A. Salam. 2007. Productivity Potentials of Salt Affected Areas: Insights from Farm Level Survey. Paper presented in the International Conference on 'Managing the Coastal Land-Water Interface in Tropical Delta Systems', held in Bangsaen, Thailand, 7-10 November.

Bangladesh Bureau of Statistics (BBS). 2008, 2009, 2010. Statistical Year Book of Bangladesh, Statistics Division, Ministry of Planning, Government of the People's Republic of Bangladesh, Dhaka.

Bangladesh Rice Research Institute (BRRI), 2009, 2010, BRRI Annual Report, BRRI, Gazipur-1701,

Bhuiyan, N. I., D. N. R. Paul and M. A. Jabber. 2002. Feeding the Extra Millions. In: Proceedings of the BRRI-DAE Workshop on Experiences of HYV Rice Production in Bangladesh, Bangladesh Rice Research Institute, Gazipur-1701.

Biswas. J. C., M. Maniruzzaman. M. A. Sattar and M. G. Neogi. 2004. Increasing Land productivity through Improved Cropping Patterns at farmers' field. In: J. C. Biswas, M. Maniruzzaman and S. A. Sattar (ed), Proc. of the Workshop on Integrated Crop Management in North-west Region of Bangladesh; Comtech Offset Press.

Department of Agricultural Extension (DAE). 2009. Annual Report on crop production status; Field services wing, DAE, Khamar bari, Farm gate , Dhaka.

Hossain. M. 2007. Rice Research, technological progress and poverty: the Bangladesh case, In: Adato. M., R. S. Meinzen-Dick, Agricultural Research, livelihoods and poverty: studies of economic and social impact in six countries, IFRI, Washington. 
Hossain, M., M. Asaduzzaman, M. A. S. Mandal, U. K. Deb and S. Jones. 2009. Rice Technologies: Strategic Choices and Policy Options, BIDS Policy Brief prepared for the National conference on 'Market Volatility, Vulnerability and Food Security: Strategic Issues and Policy Options', organized by BIDS and DFID, Dhaka, April 9, 2009.

Household Income Expenditure Survey (HIES). 2009. Bangladesh Bureau of Statistics, Statistics Division, Ministry of Planning, Government of the People's Republic of Bangladesh, Dhaka.

Husain. M. M., M. M. Rashid and M. Z. Alam. 2004. Performances of BRRI Developed MV Rice in the Coastal Saline Soils of Bangladesh. In: Proceedings of the Workshop on Integrated Nutrient Management and Water Resources Utilization for Crop Production in the Coastal saline Zone. Bangladesh Rice Research Institute, Gazipur1701, 26 June.

Jabber. M. A., and M. S. Alam. 2002. Modern Rice Technology Adoption in Rainfed Areas and Its Impact on the Rural Livelihood Pattern in Bangladesh. The Bangladesh Rural Development Studies. Vol.X(I).

Ministry of Agriculture (MOA). 2004. Land Availability for Crop Production and Future Challenges, Monitoring and Evaluation Wing, MoA, Bangladesh Secretariat, Dhaka.

Ministry of Food and Disaster Management (MoFDM). 2008. Bangladesh Food Situation Report, Food Planning and Monitoring Unit (FPMU), Food Division, MoFDM, Khadday Bhaban, Dhaka.

Ministry of Food and Disaster Management (MoFDM). 2008, 2012.Monitoring Report of the National Food Policy Plan of Action and Country Investment Plan, FPMU, Food Division, MoFDM, Khadday Bhaban, Dhaka.

Mondal M. K. 1997. Management of Soil and Water Resources for Higher Productivity of the Coastal Saline Rice lands of Bangladesh, Unpublished PhD thesis, University of the Philippines, LosBanos, Laguna, Philippines.

Mujeri, M. K, N.Ahmed and M.I.Hossain. 2012. Improving Food Security through Value Chain Management: A Study of Rice Value Chains in Bangladesh. Paper presented at the research seminar under Bangladesh Policy Research and Strategy Support Program (PRSSP), organized by USAID,IFPRI and BIDS, Dhaka, 19-20 June.

Panaullah, G. M, M. A. Salam., A. K. M Azmal, S. M. R. Karim, S. M. Shahidullah, M. N. Bari and N. N.Choudhury. 2000. Evaluation of rice germplasm suitable for the coastal saline soils of Bangladesh under fluctuating salinity, In: IFAD Annual Report for validation and delivery of new technologies for increasing productivity of floodprone rice lands of South and South east Asia.

Panaullah, G. M. 1999. Integrated Management for Sustainable Use of Salt Affected Soils: Bangladesh Country Paper presented in the International Workshop on 'Integrated Management for Sustainable Use of Salt Affected Soils', Manila, Philippines, 26-30 July.

Saleque, M. A., N. N. Choudhury, S. M. R. Karimand G. M Panaullah. 2005. Mineral Nutrition and Yield of Four Rice Genotypes in the Farmers' Fields of Salt Affected Soils, Journal of Plant Nutrition, 28:5 p865-876. 